\title{
Feasibility Study of Geometrical Parameters of Wood Transportation Roads Including Prediction of Optimum Terms of Construction and Retrofitting Sequence
}

\author{
Aleksey Vasilyevich Skrypnikov ${ }^{1}$, Vyacheslav Gennadievich Kozlov ${ }^{2, *}$, Vladimir Anatolyevich Zelikov ${ }^{3}$, \\ Petr Viktorovich Tikhomirov ${ }^{4}$, Dmitry Mikhailovich Levushkin ${ }^{5}$, Vladimir Valentinovich Nikitin ${ }^{5}$, \\ Roman Viktorovich Mogutnov ${ }^{1}$, Pavel Aleksandrovich Sokol ${ }^{6}$ \\ ${ }^{1}$ Voronezh State University of Engineering Technologies, Voronezh, Russian Federation \\ ${ }^{2}$ Voronezh State Agrarian University named after Emperor Peter the Great, Voronezh, Russian Federation \\ ${ }^{3}$ Voronezh State Forest Engineering University named after G.F. Morozov, Voronezh, Russian Federation \\ ${ }^{4}$ Bryansk State University of Engineering and Technology, Bryansk, Russian Federation \\ ${ }^{5}$ Mytishchi Branch of Bauman Moscow State Technical University (National Research University), Mytishchi, Moscow Region, \\ Russian Federation \\ ${ }^{6}$ Military Training and Research Center of the Air Force "Air force Academy named after Professor, N.E. Zhukovsky and Y.A. \\ Gagarin", Voronezh, Russian Federation
}

Received July 7, 2021; Revised September 15, 2021; Accepted October 17, 2021

\section{Cite This Paper in the following Citation Styles}

(a): [1] Aleksey Vasilyevich Skrypnikov, Vyacheslav Gennadievich Kozlov, Vladimir Anatolyevich Zelikov, Petr Viktorovich Tikhomirov, Dmitry Mikhailovich Levushkin, Vladimir Valentinovich Nikitin, Roman Viktorovich Mogutnov, Pavel Aleksandrovich Sokol , "Feasibility Study of Geometrical Parameters of Wood Transportation Roads Including Prediction of Optimum Terms of Construction and Retrofitting Sequence," Civil Engineering and Architecture, Vol. 9, No. 6, pp. 2077-2083, 2021. DOI: 10.13189/cea.2021.090635.

(b): Aleksey Vasilyevich Skrypnikov, Vyacheslav Gennadievich Kozlov, Vladimir Anatolyevich Zelikov, Petr Viktorovich Tikhomirov, Dmitry Mikhailovich Levushkin, Vladimir Valentinovich Nikitin, Roman Viktorovich Mogutnov, Pavel Aleksandrovich Sokol (2021). Feasibility Study of Geometrical Parameters of Wood Transportation Roads Including Prediction of Optimum Terms of Construction and Retrofitting Sequence. Civil Engineering and Architecture, 9(6), 2077-2083. DOI: 10.13189/cea.2021.090635.

Copyright@2021 by authors, all rights reserved. Authors agree that this article remains permanently open access under the terms of the Creative Commons Attribution License 4.0 International License

\begin{abstract}
The methods of optimum design of road longitudinal profile for various purposes, allowing eliminating subjective decisions, are developed and implemented by various research establishments. These methods are based on a deep theoretical background; they are automated but characterized by certain serious drawbacks. Firstly, the use of the minimum amount of excavation works as a criterion of optimality cannot provide an optimum solution regarding a definite period, because traffic intensity and its annual increase are not taken into account. Secondly, the proposed methods do not stipulate the necessity of stepwise development of road geometrical elements and their comprehensive substantiation. Finally, the optimization programs of design lines of the longitudinal profile are complicated and cannot be always applied in small design bureaus. This
\end{abstract}

work, being based on the presented features of analyzed publications and the necessity of their further development, is aimed at the development of methods and recommendations for a feasibility study of main parameters of transversal and longitudinal profiles of wood transportation roads including prediction of optimum terms of construction and retrofitting sequence. Achievement of the formulated purpose is mainly determined by mutual links and the structure of elements considered in this work. For clear determination of subordination of these elements, their influence on techno-economic calculations, and systematization of the overall process, it is necessary to develop a logical model of the problem. Another step to achieve the goal is a mathematical description of links of the logical scheme, that is, the development of the mathematical model of the solution. Since the solution 
assumes searching for optimum parameters, the mathematical model should be based on the target function with its extremum corresponding to the required optimum combination of the optimized elements. Several variants and the search area are defined by the required limitations.

Keywords Capital Costs, Route, Wood Transportation Road, Construction, Feasibility Study

\section{Introduction}

The specifics of the design of geometric elements of roads (plan, longitudinal and transverse profiles) allow distinguishing their feasibility study into an independent task. The geometric elements of a logging road should ensure the movement of logging rolling stock of certain intensity with an economically feasible speed for a certain estimated period. Therefore, the optimal design of geometric elements is associated with the assignment of economically rational terms for their change.

When assigning geometric parameters of roads, a comparison of options is currently used, which, for a certain degree allows subjectivity in the design. Using optimal design methods in the justification of design decisions ensures the achievement of higher efficiency in road construction investment.

Studying the ways to increase the economic efficiency of stage-by-stage improvement of transport and operational indicators of logging roads is based on the study of patterns reflecting the influence of road elements on the main transport and operational indicator - the traffic speed. Besides, it is necessary to study the impact of natural factors (terrain) on the amount of costs required for the construction of a road meeting a given technical level.

Employing the methodology of system analysis and mathematical economic methods is possible only based on using modern information technologies, which allow solving multivariate problems and combining the creativity of a specialist with the high-speed operation of the computer. Using highly effective tools and methods allows solving the actual problems of designing logging roads associated with the comprehensive optimization of geometric elements and the timing of their step-by-step improvement.

To arrange numerous parameters, links, and to determine means of substantiation of geometrical properties of wood transportation roads, it would be reasonable to apply system analysis: one of the tools of decision-making theory.

The main and the most valuable result of the system analysis are increased understanding of the problem and its possible solutions. S. Optner [1] defines a problem as follows: a problem can be defined as a situation in which there are two states; one is characterized by the present (or existing) state, the other - by a proposed (or desired) state.

The character and the composition of the desired system are determined by preset research objectives and formulated problems.

The purpose of the present study is to compensate for the shortcomings of existing methods of technical and economic feasibility of the geometric parameters of logging roads by taking into account the effects of road conditions on the construction order.

The research goal is to determine the status of the automated design system of logging roads which would correspond to the minimum value of the objective function.

Taking into account the probabilistic pattern of distribution of traffic velocities in time and space, it is necessary to stipulate for online computations employing information technologies so as to obtain a subsystem of a future system of automated designing system of wood transportation roads.

\section{Methods}

Analysis of the required system is subdivided into five distinct finite elements characteristic for the study of any system and subsystems:

1. Objective. Determination of optimum parameters of longitudinal and transversal profiles of wood transportation roads including substantiated terms of road commissioning with predefined technical levels according to increase in traffic intensity.

2. Alternative means to achieve the objective. In the case of determination of optimum terms of the sequence of construction and retrofitting or, in other words, the optimum strategy of development, and, in particular, its geometrical elements, the alternative variants are comprised of the variants of distribution of capital expenses in time. In addition to variation in time, the road technical state is also varied. In this case, the technical state is a combination of plan, longitudinal and transversal profiles, i.e., the elements of the technical state determining the road technical level.

When one of the elements characterizing the technical state is changed, it is assumed that the road is converted into another state.

3. Consumption of resources required for each alternative. In terms of costs, each variant of strategy is comprised of two contradictory subsystems. The first of them is the subsystem of capital expenses. Capital expenses corresponding to each technical state of the road are determined by estimated cost.

Upon transition to a higher technical state, the consumed resources should equal the difference of estimated costs plus the sum required for reorganization of the works. While planning supplemental expenses for a 
long-term period, they should be reduced to the initial year:

$$
C_{\left(t^{i j}\right)}=\frac{\left(C_{j}-C_{i}\right) \eta}{e^{t i j}}
$$

where $C_{i}$ is the estimated cost of the technical state with low indicators; $\mathrm{C}_{j}$ is the estimated cost of the technical state with higher indicators; $\eta$ is the coefficient of increase in capital expenses upon stepwise construction (according to Katz: $\eta=1.1$ ) [2]; $e^{t i j}$ is the year of transition from the state $i$ to the state $\mathrm{j}$.

The second subsystem presents transportation and maintenance expenses. Analysis of operation of motor transport demonstrates that the change of expenses related with transportations depends on traffic velocity [3]. Annual transportation expenses in a general form can be expressed as follows:

$$
\mathrm{M}=\mathrm{f}\left[N_{0} f(t): S: V_{t}\right]
$$

where $N_{0}$ is the traffic intensity in the initial year, car/day; $V_{t}$ is the average technical velocity during the year $\mathrm{t}, \mathrm{km} / \mathrm{h} ; \mathrm{S}$ is the prime cost of transportation, basic currency/car'h.

4. Logical and mathematical models. Development of solution procedure should be reasonably started with the construction of the logical model. Analysis of mathematical model of the feasibility study should be carried out after preset of all system objects and links. Construction of the logical structure of the problem solution is comprised of the establishment of interrelations among the system elements, element hierarchy, and determination of system objects: input, process, output, and feedback [4-7]. The system logical model is schematically illustrated in Figure 1.

The symbols $\mathrm{R}, \mathrm{P}, \mathrm{W}$ in the scheme denote the main position of the route, longitudinal profile, and the roadway width or the number of traffic lanes, that is, transversal road profile. The terms $C(R), C(P)$, and $C(W)$ express portions of capital investments per element.

The input parameters of the system are the traffic intensity $N_{0}$ in the initial year of operation $t_{0}$, increasing in time, the parameter $\mathrm{x}=\mathrm{f}(\mathrm{t})$ expressing annual increase in traffic intensity, the parameter $\mathrm{R}$ characterizing traffic composition and natural factors, in particular, terrain relief.
The mentioned input parameters with regard to problem solution with derivative are the independent control parameters. Indeed, the time intervals of activities improving the road technical state and the type of these activities are completely determined by these four parameters. Therefore, while determining the system input parameters, we preset its control.

Optimum distribution of capital expenses in time and optimum parameters of the road are determined in the set of variants' combinations belonging to three groups of subsets. The first group is presented by the subset of possible route positions in the plan $\left(m_{t}\right)$, the second group - by subset of variants of longitudinal profile $\left(m_{l}\right)$, and the third group - by the subset of types of transversal profiles $\left(m_{t}\right)$.

Thus, the number of possible technical states is determined as follows:

$$
z=m_{t} \cdot m_{l} \cdot m_{t}
$$

Each element of the technical state corresponds to the cost indicator $\mathrm{C}$, the sum of the cost indicators determines capital expenses required for the achievement of each technical state. The system output parameters depend on the technical state and are characterized by the distribution of traffic velocities (the primary output parameter), presented by its statistical properties $\bar{v}$ and $\bar{\sigma}$, and the secondary output parameters: annual transportation and maintenance expenses (m).

It should be mentioned that the road structure in the system does not vary and is presented in the form of influence on the cost of achievement of technical state, and traffic velocity. The coating type is changed according to the increase in roadway width.

5. Criterion of selection of preferred variants. The most suitable for solving the problems of stepwise development of transportation lines in time is the criterion of optimality, characterized by minimum maintenance and capital expenses reduced to the initial year. The criterion of minimum reduced expenses reflects most completely the features of road construction, allowing to account for continuous increase in cargo turnover and the time interval of capital investments. 


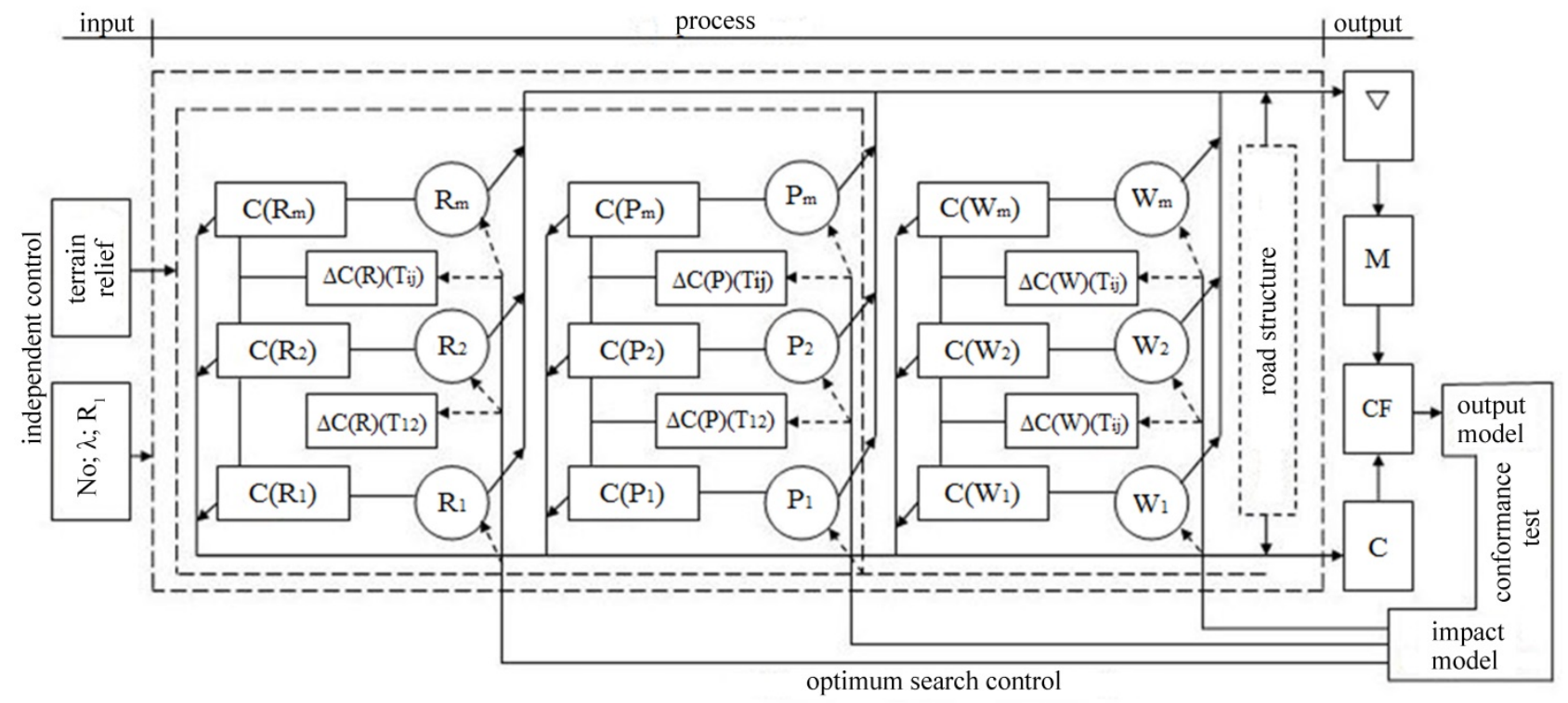

Figure 1. Logical scheme of searching for the optimum strategy of wood transportation road development

\section{Results and Discussion}

Most researchers have concluded that this criterion is the best for the formulated objective [8-11].

During searching for an optimum solution, the criterion acts as the control function, that is, corresponds to the subsystem of feedback. The feedback operation is based on its three constituents: a) model of output, which is a certain hypothetical value of cumulative reduced expenses; in other words, the model of output includes the requirements to the system; b) conformance test of the model of output is performed for each variant until the desired alternative is found having minimum reduced expenses; c) impact model. In the case of noncorrespondence of cumulative reduced expenses in any variant of the strategy to the minimum value, the next alternative should be tested. A new combination of elements was composed for this aim characterizing the technical state and times of transition from one state to another. The composition of a new variant is an impact on the system.

The feedback system operates from the time of calculation of $\mathrm{C}$ for two variants until the variant $\mathrm{C}_{\min }$ was determined.

Since the active control of searching is performed using the feedback subsystem, which contains requirements to the system and criteria of selection of preferred alternative, the mathematical model is based on control function representing the equation of cumulative reduced expenses:

$$
\begin{gathered}
\mathrm{CF}=C_{0}+\int_{0}^{t_{1}} \frac{M_{0}}{e^{E t}} d t+\frac{K_{1}}{e^{E t_{1}}}+\int_{t_{1}}^{t_{2}} \frac{M_{1}(t)}{e^{E t_{m}}} d t+\cdots+\frac{K_{m}}{e^{E t_{m}}}+ \\
\int_{t_{m}}^{T_{p}} \frac{M_{m}(t)}{e^{E t}} d t
\end{gathered}
$$

The main constituents of the target function depend on phase coordinates of the system and on independent control:

$$
\begin{gathered}
\mathrm{C}=\mathrm{f}(\mathrm{p} ; \mathrm{R} ; \mathrm{W} ; \mathrm{Rl} ; \mathrm{t}) \\
\mathrm{M}=\mathrm{f}\left[\mathrm{P} ; \mathrm{R} ; \mathrm{W} ; \bar{v}\left(N_{0} \lambda ; R l\right) ; t\right]
\end{gathered}
$$

where $\mathrm{Rl}$ is the relief property.

The search objective was determining phase coordinates of the system corresponding to independent control at a minimum of the control function.

In addition, the mathematical model was determined by the link structure (6) and system limitations.

To be included in the mathematical model and to facilitate calculations, the elements of road technical state should be presented by reliable estimations. Herewith, the estimations should precisely reflect the actual impacts of geometrical parameters for both parts of the target function.

Designed slopes are characteristic and determining elements of the longitudinal profile. The velocity of timber trucks under free traffic conditions depends the most on the slope in comparison with other elements of longitudinal profile [12-15]. In addition, significant influence is also exerted by the relative distance of segments with various values of longitudinal slopes and the amount of excavation works. These circumstances sufficiently substantiate the selection of the longitudinal slope distribution as an estimation of the longitudinal profile. The type of this distribution, its properties and interrelation with other parameters characterizing technical state can be determined experimentally upon analysis of road projects. In addition, the distribution of traffic velocities and transportation/maintenance properties should be experimentally determined as a function of the distribution of longitudinal slopes. Thus, the following quantitative links of the mathematical model were determined experimentally: 
1) $\mathrm{C}=\mathrm{f}(\mathrm{P} ; \mathrm{Rl})$

2) $\bar{v}=f(P ; W ; N)$

3) $\sigma_{v}=f(P ; W ; N)$

The limitations were as follows:

1. Upon stepwise improvement of technical state, only transition from lower to higher state was possible. In addition, the times of transitions were arranged as follows:

$$
t_{1}<t_{2}<\cdots<t_{n}<T_{p}
$$

2. It was assumed that during the design period $T_{p}$ the longitudinal profile can change in some cases only once. The property of the route plan (R) remains steady and varies for determining its initial value.

3. The required limitations should be imposed on the search area of optimum solution, that is, the boundary conditions of phase coordinates of the system should be determined.

Regarding time, the search area was determined by the interval of $T_{p}=30$ years. This value was selected from the conditions of advanced planning with consideration for the time factor. Beyond the predicted time period, the influence of the time factor is so significant that the cost indicators decrease to the values not exceeding the computation accuracy.

Limitations of the search area in space completely depend on the terrain relief, and the number of possible technical states - on the size of the search step.

Along the determined direction of the route with known relief, the number of possible variants of the longitudinal profile was determined by the number of steps at the gradual increase of profile complexity from the variant coinciding with a hypothetical line with zero slope connecting initial and final points of the route to the variant repeating the ground profile (Figure 2).

In the case of route expansion, the ground profile has lower longitudinal slopes, thus, the number of possible variants of designed longitudinal profile decreases.

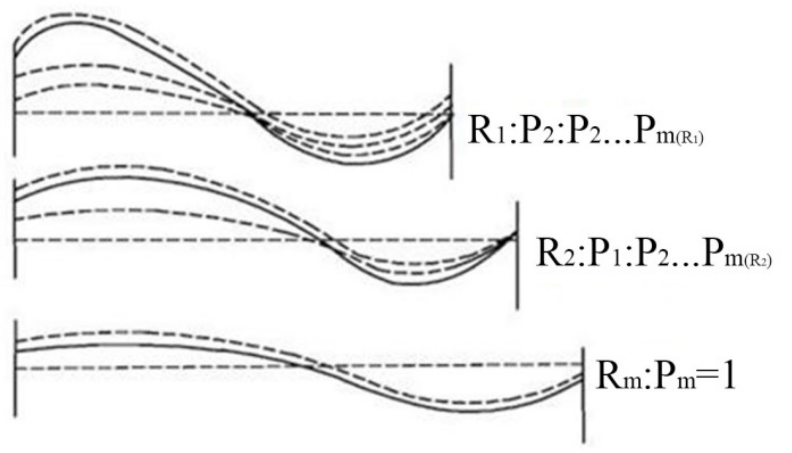

Figure 2. Determination of search area $\mathrm{R}$ and $\mathrm{P}$

Development of the route with a certain gradation of the coefficient of elongation would result in the case when already at the first step the designed line of longitudinal profile coincides with earth level. This variant restricts the search area regarding the route construction length (Figure 2). Concerning the number of variants of the transversal profile, the solution is selected depending on the road purpose, initial traffic intensity, and expected rates of its increment. In addition, it is necessary to stipulate the opportunity of improvement of the road technical state regarding the roadway width or traffic lanes with minimum expenses and dumped works.

Taking into account the features of construction of mathematical model, Eqs. (5), (6), (7), as well as the recommendations in [16-21], the equation of cumulative reduced expenses (4) can be presented as follows:

$$
\begin{aligned}
& \mathrm{C}=\mathrm{C}(\mathrm{RL}, \mathrm{P}, \mathrm{R}, \mathrm{W})+\int_{\mathbf{0}}^{\mathrm{t}_{1}} \mathrm{M}\left\{( \mathbf { N } _ { \mathbf { 0 } } \boldsymbol { \lambda } , \mathrm { R } ) \left[\frac{\mathbf{a}+\mathbf{b} \overline{\mathbf{v}}\left(\mathrm{P}, \mathbf{N}_{\mathbf{0}} \boldsymbol{\lambda}, \mathrm{W}, \mathrm{Rl}\right)}{\overline{\mathbf{v}}\left(\mathrm{P}, \mathbf{N}_{\mathbf{0}} \boldsymbol{\lambda}, \mathrm{W}, \mathrm{Rl}\right)}+\right.\right. \\
& \left.\left.+\mathrm{S}_{\mathrm{p}}(\mathrm{P}, \mathrm{W})\right]\right\} \frac{\mathbf{d t}}{\mathbf{e}^{\mathrm{Et}}}+\frac{\mathbf{K}_{\mathbf{1}}\left(\mathrm{RL}, \mathrm{R}^{1}, \mathrm{P}^{1}, \mathrm{~W}^{1}\right)}{\mathbf{e}^{\mathrm{Et}_{1}}}+ \\
& +\int_{t_{1}}^{t_{2}} M_{1}\left\{( N _ { 0 } \lambda , R ^ { 1 } ) \left[\frac{\mathbf{a}+\mathbf{b} \overline{\mathbf{v}^{1}}\left(\mathrm{P}^{1}, \mathbf{N}_{0} \lambda, W^{1}, \mathrm{Rl}\right)}{\overline{\mathbf{v}^{\mathbf{1}}}\left(\mathrm{P}^{\mathbf{1}}, \mathbf{N}_{\mathbf{0}} \boldsymbol{\lambda}, \mathrm{W}^{\mathbf{1}}, \mathrm{Rl}\right)}+\right.\right. \\
& \left.\left.+\mathrm{S}_{\mathrm{p}}{ }_{\mathrm{p}}\left(\mathrm{P}^{1}, \mathrm{~W}^{\mathbf{1}}\right)\right]\right\} \frac{\mathbf{d t}}{\mathbf{e}^{\mathrm{Et}}}+\cdots+\frac{\mathbf{K}_{\mathrm{m}}\left(\mathrm{RL}, \mathrm{R}^{(\mathbf{m})}, \mathrm{P}^{(\mathbf{m})}, \mathrm{W}^{(\mathbf{m})}\right)}{\mathbf{e}^{\mathrm{Et}_{\mathbf{m}}}}+ \\
& +\int_{\mathbf{t}_{\mathbf{m}}}^{\mathrm{T}_{\mathbf{p}}} \mathrm{M}_{\mathbf{m}}\left\{( \mathbf { N } _ { \mathbf { 0 } } \lambda , \mathrm { R } ^ { \mathbf { m } } ) \left[\frac{\mathbf{a}+\mathbf{b} \overline{\mathbf{v}^{(\mathbf{m})}}\left(\mathrm{P}^{(\mathbf{m})}, \mathbf{N}_{\mathbf{0}} \boldsymbol{\lambda}, \mathrm{W}^{(\mathbf{m})}, \mathrm{Rl}\right)}{\overline{\mathbf{v}^{(\mathbf{m})}}\left(\mathrm{P}^{(\mathbf{m})}, \mathbf{N}_{\mathbf{0}} \lambda, \mathrm{W}^{(\mathbf{m})}, \mathrm{Rl}\right)}+\right.\right. \\
& \left.\left.+\mathbf{S}^{(\mathbf{m})}{ }_{\mathrm{p}}\left(\mathrm{P}^{(\mathbf{m})}, \mathrm{W}^{(\mathbf{m})}\right)\right]\right\} \frac{\mathrm{dt}}{\mathrm{e}^{\mathrm{Et}}},
\end{aligned}
$$

where $\mathrm{R}, R^{1} \ldots R^{m}$ are the properties of the planned position of the road route upon varying from the variant $\mathrm{R}$ to the variant $R^{m}$;

$\mathrm{P}, P^{1}, \ldots P^{(m)}$ are the properties of the longitudinal profile upon varying from the variant $\mathrm{P}$ to the variant $P^{(m)}$;

$\mathrm{W}, W^{1} \ldots W^{(m)}$ are the characteristics of the transverse profile when varying from variant $\mathrm{W}$ to variant $W^{(m)}$;

$\bar{v}$ is the average traffic velocity;

$C_{0}, K_{1}, \ldots K_{m}$ are the capital investments for technical states determined by the elements R;P;W; $R^{1}, P^{1}, W^{1} ; R^{(m)}, P^{(m)}, W^{(m)}$

a is the constant not depending on the transportation velocity;

$\mathrm{w}$ is the constant depending on the traffic velocity;

$S_{p}$ is the damage resulting from traffic accidents;

$N_{0}$ is the traffic intensity in the base year;

$V_{t}$ is the average technical speed of traffic during the year;

$\mathrm{S}$ is the cost of transportation;

$\mathrm{T}$ is the time.

Determination of route plan, longitudinal profile, and roadway width, corresponding to a minimum of Eq. (9), 
was performed by their variation in the preset search area. Searching for optimum times of improvement of the road technical state regarding geometrical parameters was also performed by varying transitions and states in time with accounting for limitations.

\section{Conclusions}

Based on theoretical preconditions, the system of links and parameters has been derived to determine the research targets. The structure of the solution and its main elements have been determined. The system analysis applied to the issue of the design of wood transportation roads has demonstrated that this procedure is an efficient tool providing a more detailed understanding of the problem, determining solutions to the problem and their algorithmization.

The presented target function is the main part of the mathematical model of the feasibility study of plan elements of wood transportation roads.

\section{REFERENCES}

[1] V. F. Babkov. Dorozhnye usloviya i bezopasnost' dvizheniya [Road conditions and traffic safety], Transport, Moscow, 1993.

[2] D. L. Drew. Traffic Flow Theory \& Control, McGraw Hill, New York, 1964.

[3] V. G. Kozlov. Mathematical modeling of damage function when attacking file server, Journal of Physics: Conference Series, Vol.1015, 032069, 2018.

[4] V. G. Kozlov, V. A. Gulevsky, A. V. Skrypnikov, V. S. Logoyda, A. S. Menzhulova. Method of individual forecasting of technical state of logging machines, IOP Conference Series: Materials Science and Engineering, Vol.327, No.4, 042056, 2018. https://doi.org/10.1088/1757 $-899 X / 327 / 4 / 042056$

[5] A. V. Skrypnikov, S. V. Dorokhin, V. G. Kozlov, E. V. Chernyshova. Mathematical model of statistical identification of car transport informational provision, Journal of Engineering and Applied Sciences, Vol.12, No.2, 511-515, 2017.

[6] Ya. A. Kaluzhskii, I. V. Begma, V. M. Kislyakov, V. V. Filippov. Primenenie teorii massovogo obsluzhivaniya $v$ proektirovanii avtomobil'nykh dorog [Theory of queuing in design of motor roads], Transport, Moscow, 1969.

[7] A. V. Skrypnikov, V. G. Kozlov, D. V. Lomakin, E. Yu. Mikova. Otsenka vliyaniya na skorost' dvizheniya postoyannykh parametrov plana i profilya pri razlichnykh sostoyaniyakh poverkhnosti dorogi [Traffic velocity as a function of layout and profile upon various states of road surface], Forestry Bulletin, Vol.21, No.6, 43-49, 2017.

[8] E. V. Chernyshova. Metody formirovaniya tsifrovoi modeli mestnosti pri trassirovanii lesovoznykh avtomobil'nykh dorog [Formation of digital model of terrain upon location of wood transportation roads], Sistemy. Metody. Tekhnologii, Vol.3, No.35, 143-148, 2017.

[9] V. G. Kozlov, A. V. Skrypnikov, E. V. Chernyshova, E. V. Chirkov, S. A. Postavnichii, R. V. Mogutnov. Teoreticheskie osnovy i metody matematicheskogo modelirovaniya lesovoznykh avtomobil'nykh dorog [Theoretical foundations and methods of mathematical simulation of wood transportation roads], IVUZ Lesnoi zhurnal, Vol.6, No.366, 117-127, 2018.

[10] V. A. Gulevskii, A. V. Skrypnikov, V. G. Kozlov, D. V. Lomakin, E. Yu. Mikova. Eksperimental'naya otsenka stsepnykh kachestv i rovnosti pokrytii pri razlichnykh sostoyaniyakh avtomobil'nykh dorog i pogodnykh usloviyakh [Experimental estimation of coupling properties and coating flatness upon various states of motor roads and weather conditions], Vestnik Voronezhskogo gosudarstvennogo agrarnogo universiteta, Vol.11, No.1(56), 112-118, 2018.

[11] A. I. Zavrazhnov, A. N. Belyaev V. A. Zelikov, P. V. Tikhomirov, N. V. Mikheev. Designing mathematical models of geometric and technical parameters for modern road-building machines versus the main parameter of the system, In: Atlantis Highlights in Material Sciences and Technology. Proceedings of the Int. Symposium "Engineering and Earth Sciences: Applied and Fundamental Research" dedicated to the 85-th anniversary of H.I. Ibragimov (ISEES 2019) (pp. 823-827), Atlantis Press, 2019.

[12] O. Berestnev, Y. Soliterman, A. Goman. Development of scientific bases of forecasting and reliability increasement of mechanisms and machines - one of the key problems of engineering science. In: M. Ceccarelli (ed.) International Symposium on History of Machines and Mechanisms Proceedings (pp. 325-332), Springer, Dordrecht, Netherlands, 2000.

[13] V. N. Ivanov, V. N. Erokhov. Vliyanie parametrov avtomobil'nykh dorog na raskhod topliva [The influence of motor road parameters on fuel consumption], Avtomobil'nye dorogi, No.8, 10-13, 2014.

[14] A. K. Birulya. Ekspluatatsiya avtomobil'nykh dorog [Motor road maintenance], Transport, Moscow, 1966.

[15] V. G. Kozlov, A. V. Skrypnikov, E. Yu. Mikova, R. V. Mogutnov, Yu. A. Zelikova. Kompleksnye eksperimental'nye issledovaniya izmeneniya parametrov i kharakteristik dorozhnykh uslovii, transportnykh potokov i rezhimov dvizheniya pod vliyaniem klimata i pogody [Comprehensive experimental studies of parameters and properties of road conditions, transport flows and traffic modes under the influence of climate and weather], Lesotekhnicheskii zhurnal [Forestry Engineering Journal], Vol.8, No.2(30), 156-168, 2018. https://doi.org/10.12737/a rticle_5b240611858af4.37544962

[16] V. G. Kozlov. Methods, models and design algorithms of wood transportation roads with consideration for the influence of climate and weather on traffic conditions: Doctoral Thesis, SAFU, Arkhangel'sk, Russia, 2017.

[17] E. V. Kondrashova, T. V. Skvortsova. Sovershenstvovanie organizatsii dorozhnogo dvizheniya $\mathrm{V}$ transportnykh 
sistemakh lesnogo kompleksa [Improvement of traffic arrangement in transport systems of timber complex], Sistemy upravleniya i informatsionnye tekhnologii, Vol.3.2, No.33, 272-275, 2008.

[18] V. V. Sil'yanov, Yu. M. Sitnikov. Raschet skorostei dvizheniya pri proektirovanii avtomobil'nykh dorog [Prediction of traffic velocities upon designing of motor roads], MADI, No.72, 47-66, 1974.

[19] V. G. Kozlov, A. V. Skrypnikov, E. Yu. Mikova, R. V. Mogutnov, E. V. Chirkov. Formirovanie modeli proektirovaniya sistemy "dorozhnye usloviya transportnye potoki" i puti ee realizatsii [Formation of the model of designing the system "road conditions - transport flows" and ways of its implementation], Lesoinzhenernoe delo, Vol.8, No.1(29), 100-111, 2018. https://doi.org/10.1 2737/article_5ab0dfbe6ece23.91630316

[20] N. U. Barus, J. Sjah, A. D. Rarasati. Performance Evaluation of Woven Polyethylene Formwork on Tie Beam and Pile Cap Structure in Terms of Cost and Time, Civil Engineering and Architecture, Vol.8, No.3, pp. 305-311, 2020. https://doi.org/10.13189/cea.2020.080314.

[21] D. Santoso, T. Tjahjono. Determination Minimum Distance between Ramp Entry and Exit on the Freeway Reviewed from the Road Safety Aspect, Civil Engineering and Architecture, Vol.8, No.3, pp. 268-273, 2020. https://doi.org/10.13189/cea.2020.080309. 